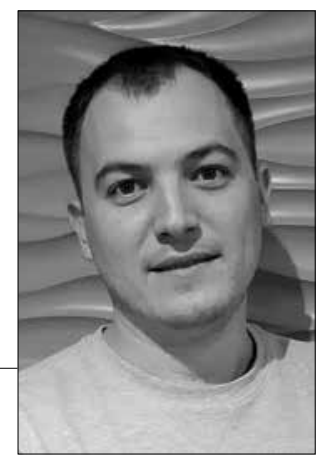

\title{
KALBOS INOVACIJŲ ELEKTRONINĖS KARTOTEKOS KÜRIMO SAMPRATA (MEDIAEKOLOGINIS ASPEKTAS)
}

\section{Concept of Creating an E-Filing System of Language Innovations (Media and Ecological Aspect) ${ }^{1}$}

\begin{abstract}
SUMMARY
The article analyzes language innovations that function in mass media communication. These innovations represent the information space of Ukraine from the point of view of media ecology and ecolinguistics. The proposed concept of creating an e-filing system of language innovations, will present these innovations on the web portal by several functional characteristics: the sphere from which the innovation entered the mass consciousness, the genre in which media innovation functioned for the first time, the psycholinguistic marker (Shevchenko, Syzonov 2019), the time of appearance of a new unit and derived innovations, extralingual factors. As a result, this will allow us to talk about the continuous updating of the lexical and phraseological fund of the Ukrainian language in the media, which proves the dynamics of modern language processes. The proposed research from the point of view of media ecology is innovative for Ukrainian linguistics, and therefore requires a wide field for discussion on the part of modern specialists based on innovative ideas of an interdisciplinary nature.
\end{abstract}

\section{SANTRAUKA}

Straipsnyje mediju ekologijos ir ekolingvistikos požiūriu analizuojamos kalbų inovacijos, kurios veikia žiniasklaidos komunikacijoje ir atspindi Ukrainos informacinę erdvę. Siūloma kalbos inovacijų elektroninès kartotekos sukūrimo koncepcija, kurią ateityje interneto portale reprezentuos kelios funkcinės charakteristikos: sritis, iš kurios inovacija pateko į masinę sąmonę, žanras, kuriame žiniasklaidos inovacija funkcionavo pirmą kartą, psicholingvistinis žymeklis (Shevchenko, Syzonov 2019), naujojo vieneto ir išvestinių naujovių, ekstralingvistinių faktorių atsiradimo laikas. Tai leistų mums kalbėti apie nuolatinį ukrainiečių kalbos leksikos ir 
frazeologinio fondo atnaujinimą žiniasklaidoje, nes jis įrodo šiuolaikinių kalbos procesų dinamiką. Medijų ekologijos požiūriu atliktas tyrimas ukrainiečiu lingvistikoje yra novatoriškas, todèl šiuolaikiniams specialistams reikalingas platus diskusijų laukas, pagrịstas novatoriškomis tarpdisciplininio pobūdžio idèjomis.

\section{INTRODUCTION}

The project "Ecolinguistic Modes of Discursive Space of Ukraine in the European Multicultural Continuum", within the framework of which the research is carried out, depicts an ecological portrait of a Ukrainian and gives a comprehensive analysis of modern parameters of ecology in the Ukrainian language. Previously, the project participants have already proved the importance of ecolinguistic neo direction, focusing on its innovativeness:

"For the concept of ecolinguistic modes as cognitive-semiotic structures of language / communicative eco-consciousness, the ratio and commonality of the functional potential of language and speech dominants are important, which are actually responsible for preserving and ensuring the ecology of discursive space / environment and national language security" (Korolyov 2021: 103).

Obviously, the dynamic communication processes that the modern speaker responds to are the key to complex Ukrainian portraying. These processes include mass media which are "a mirror of modern society. They play an important role and determine the social, economic, cultural, and educational development of the country" (Shevchenko, Syzonov, Dergach 2014: 59). Therefore, the consideration of mass media in the context of ecological problems is relevant and is defined by us as a priority in the socio-humanitarian research space. In this context, let us recall D. Perrin - a well-known German media language researcher who emphasized the priority of media institutions in spreading language changes among the masses (Perrin 2006).

In the 21st century, Digital Age as a globalized information reality is defined by the main characteristics: mobility, information saturation, dynamism in the presentation of facts, objectivity, etc. All this implies a connection with media ecology (i.e. the purity of presenting the information in the media stream). And here it is important not to lose the information truth in the huge whirlpool of media competitiveness; "description of new realities of information competitiveness" (Momaya 2019: 2). We emphasize that today the aspect of "truth and post-truth" in the media flow remains important, and areas of responsibility for information in the media space are being rethought (Deslandes, Painter-Morland 2012). Considering mass media as a platform for promotion the language resource, in particular an innovative one, we consider it logical to develop a concept of creating a filing system in electronic format (an efiling system) for collecting and analyzing such innovations, which are the object of our research.

We emphasize that "a modern filing system should first of all track changes in the language, and not only the appearance of innovations, but also changes in the properties of already existing vo- 
cabulary" (Karpilovska 2017: 95), and therefore we consider it relevant to work on such a filing system that will help to screen the Ukrainian language as fully as possible in the mass consciousness. Especially when it comes to updating it.

In lexicographic scientific practice, the creation of a filing system of language innovations is not new: let us recall a project of German researchers U. Quasthoff, S. Liebold, N. Taubert, T. Wolf (2007), who worked on a filing system of German language innovations. There was also a project led by a Russian researcher G. Solganik (2002), who collected a filing system based on the materials of the print press of the late $20^{\text {th }}$ century. Other known academic lexicographic projects (Karpilov, Kysljuk, Klymenko, Krytska, Puzdyrjeva, Romanjuk 2013; Corpus of Ukrainian language 2003) concentrated on a filing system for the analysis of various communication spheres. The material was processed and a lexicographic and cognitive base of language innovations based on dispositions was created (Zhabotinskaya 2015). Our task is more global - to create an electronic filing system of language innovations in terms of functional and communicative parameters and with attention to the media and ecological problems of the information space of Ukraine. It should be noted that within the framework of the lexicographic project "New words and phraseologisms in Ukrainian mass media" which was implemented by Taras Shevchenko National University of Kyiv, a psycholinguistic electronic metric (Shevchenko, Syzonov 2019) was previously described, which will help to qualitatively reflect the media reality of Ukrainians in a specific time period.

\section{MEDIA ECOLOGY AND MEDIA LINGUISTICS: TOUCH POINTS}

In modern globalization processes, as already noted, the correct information flow, which would be as objective and dispassionate as possible in relation to the recipient, remains the key. We focus on the notion of media ecology in its syncretic connection with media linguistics in the context of the analyzed issue - representation of the e-filing system of language innovations in Ukrainian media.

Media ecology in the works of modern researchers is understood as a clean and unbiased media space which does not popularize the so-called "disruptions" of the media to antisocial processes (Flayhan, 2001; Ruotsalainen and Heinonen, 2015). Accordingly, the lan- guage that functions in the media must also comply with ecolinguistic principles - standardization, literary, correctness, exemplary, etc. In fact, this is (media) reality in which recipients co-exist:

The media ecology tradition perceives media as a structure in which society and culture evolve - as an environment where people act and live their lives, and through which reality is perceived. Culture and social and societal relationships are created through human communication (Ruotsalainen, Heinonen 2015).

But what about new units that break into the media space (and then into the language system), sometimes without paying attention to language laws? What 
about those language units that adapt to the new rules of each language (which takes time)? How to interpret those language innovations that function in media communication, taking into account regulatory shifts? These problems form the basis of modern media ecology (sometimes entering the field of media literacy), the solution of which requires the efforts of modern linguists. It is this broad aspect which proves that "mediaecology needs a broad analysis of how media ecology is embedded in, and advocates for, the larger move in communication studies away from narrow, quantitative effects research and towards qualitative and interdisciplinary" (Flayhan 2001: 21).

This syncretic theme has become particularly relevant in times of globalizing changes in the world. Ukraine and its independence, integration into the world information space, the evolution of the Ukrainian language in modern times, the development of media in new genre conflicts are only partial issues that media ecology in relation to media linguistics can help to solve and professionally explain.

Media ecology (as the science of the ecology of the information space) and media linguistics (as the science of media language) are interdependent: the language must meet the status of "correctness" in mass media, at the same time, the emergence of new units does not always meet this criterion, entering the language system. On this paradox, the interrelationships of these neodisciplines with a common object - mass communication - are built.

\section{SOURCE BASE: MEDIAECOLOGICAL TOUCHES}

It should be noted that the new efiling system proposed for "portraying" the Ukrainian media discourse for updating, taking into account ecological processes in the language, includes media texts of Ukraine in various formats print and electronic press, internet, advertising and PR, television and radio broadcasting. Genre and thematic syncretism of the media was also taken into account: texts of informational, analytical, political, economic, financial, cultural, artistic nature etc. Facebook, Instagram, TikTok, and the new ClubHouse networks, which are already popular among Ukrainians, have been taken into account (note that we have taken into account the language innovations of both Facebook, Instagram, and TikTok net- works that are already popular among Ukrainians).

Based on this, we cannot but pay attention to a separate media field - the Internet and electronic media, attention to which is increasingly focused from the point of view of information hygiene:

«electronic media promote a change in society by connecting previously separate social spaces and spheres with each other. Before electronic media, social spaces were tied to physical spaces. $<\ldots>$ media ecology perspective helps to complement the flaws of the so-called network society theory. According to the theory, along with the rise of information and communication technologies, hierarchical bureaucracies are being replaced with more equal and interactive networks» (Meyrowitz 1985). 
So, mass media as a source base for processing material are determined for the following reasons:

(a) a powerful and manifested influence on mass speech consciousness in all strata of society;

(b) multivariance of the functional resource of the language, which is manifested on various media (printed publications, radio, television, advertising, the Internet), the ability to fix the communicative potential of the language in a certain time frame;

(c) linguistic objectification of new language units (their semantics, lexical and syntactic compatibility) in the Ukrainian language;

(d) presentation and certification of a new phraseology that arises in the field of public communication.

We support the theory about the postinternet, which will be dominant in the information society of the 2020s (Ruotsalainen, Heinonen 2015). We also take this post-internet principle into account when we talk about creating an e-file (e-filing system) of language innovations based on both traditional and electronic media:

«post-internet refers to a society where the internet is present everywhere and which is partly defined by the internet and its uses and values. For the first time a specific communication technology would define the whole of society from its economy to its culture» (Ruotsalainen, Heinonen 2015).

New times also create new requirements for internet media that would meet the needs of the recipient - to receive information quickly, easily and honestly. It is this triad that interests us when it comes to developing an e-file (e-filing system) from a media ecological perspective.

\section{COLLECTION OF MATERIAL AND DESCRIPTION OF THE E-FILING SYSTEM METHOD}

To correctly depict the portrait of the Ukrainian in the new language realities, we used the already proven method (Shevchenko, Syzonov 2019: 370-372), instead of placing media ecological accents. So, the dominant methods for further collection of the material will be:

(a) a systematic method that involves searching for new units in the system of mass communication sources. It is the wide range of mass media sources used in the framework of the project "Ecolinguistic Modes of Discursive Space of Ukraine in the European Multicultural Continuum" that allows high-quality screening of modern Ukrainian language mass communication;

(b) a search method that consists of frequency search for new units in mass media. Due to the fact that the media market is constantly updating, we are not able to follow all the language innovations that appear in modern media texts; and it is with the help of the search method that we can correctly and fully follow innovations in the Ukrainian language with an emphasis on the frequency of their functioning;

(c) the method of typological comparisons in the search and scientific certification 
of new language units was used as the leading one, which corresponds to the correctness of the presented neolexemes (a new word recorded taking into account the background knowledge of recipients is relevant for a certain analyzed period of time). Note that in media communication, the dynamism of information transmission remains the key, and therefore, using this method, we can compare the appearance of language innovations in a certain time period, proving a constant change in speech;

(d) the method of media monitoring, which is used for processing and maximizing the description of media sources in modern Ukraine. Monitoring of multigenre, multi-thematic and multi-channel sources will allow to objectify the updating of the Ukrainian language in the mass media space;

(e) an interpretive method that formed the basis for describing new language phenomena in the media. Using this method, we will be able to assess the degree of the ecology of the new unit (Lum 2006) by answering the question: does it make sense to transliterate the new unit, do you need to specify the donor language from which the unit came to the Ukrainian language, does it adapt to spelling norms, will it leave its original semantics in the future;

(f) the method of lexicographic interpretation was used to analyze the collected material, its certification and linguistic argumentation of novelty. The method will make it possible in future to lexicographically represent new units on a special website within the framework of the project of the National Research Foundation of Ukraine "Ecolinguistic Modes of Discursive Space of Ukraine in the European Multicultural Continuum".

We plan to expand the methodological base if screening sources for language innovations are ineffective. We also understand that the representation of new units on a regional basis may be uneven, which is associated with language policy and tradition in the regional press. That is why we allow correction of methods and techniques in the process of collecting neologisms in the media.

\section{EXTRALINGUAL FACTORS WHICH INFLUENCED LANGUAGE INNOVATIONS: (MEDIA + ECOLOGY)}

We consider extralingual factors that influenced the language in the context of its renewal to be the key in the emergence of new language units in the mass media. Note that the evolution of mass media is also associated with external factors of functioning: the world is changing - the media is changing; politics, culture, and the economy have clearly influenced the media. As a result, the language content of media sources has also changed. Let's highlight the main extralingual factors that influenced the emergence of language innovations in the Ukrainian media:

(a) socio-political processes. They have the greatest impact on innovation processes in speech, because they are a direct reaction of speakers to events that change the socio-political structure. First of all, we are talking about revolutions, wars, the electoral process, etc., along 
with which new concepts are added to the language (hereinafter we present selective illustrations of language innovations that have appeared in the Ukrainian language over the past 20 years): Orange Revolution $=$ Помаранчева рево^юиія, Revolution of dignity $=$ Революиія Гідності, titushki $=$ miтуик $i$, fugitive president $=$ президент-утікач, Ze-team $=$ Зе-команда, president-" chocolate king" = Президент - «щоколадний король», еtс. These innovations have become not only popular in the Ukrainian communicative reality, but also reached the general public in the world (for more information about language innovations from the time of revolutionary changes in Ukraine, see S. Zhabotinskaya (2015)). The innovations were actively formed under the influence of psychological and political factors of the evolution of communicants.

This also includes innovations related to COVID-19 / SARS-CoV-2. In Ukrainian language communication there are words associated with the new virus: coronavirus $=$ коронавірусний, coronapositive $=$ коронапозитивний, coronanegative $=$ коронанегативний , coronadependent $=$ короназалежний $;$ covid $=\kappa o-$ відний, covidpositive $=\kappa$ ковідпозитивний, covidnegative $=$ ковіднегативний, coviddependent $=$ ковідзалежний, etc. There are also derived words that carry evaluative semantics: covidiot $=$ kobidiom, covidonomics $=$ ковідономіка, "coronation" = "коронація", coronatrash = короHampeu, etc. This has also made its own adjustments for the information space: we are talking about infodemia (Zarocostas 2020) as a phenomenon in the context of the media influencing communication during the pandemic period. And we suggest talking about this phe- nomenon more globally: not as "the functioning of media institutions and the creation of media texts during a pandemic" (Cifuentes-Faura 2020: 146), but as (media) ecologically oriented media that inform recipients about the pandemic. In fact, we are talking about information hygiene during the pandemic, the logic of submitting information about COVID-19, countering "fake" messages about the pandemic and media literacy of recipients in searching for information about COVID-19. In this regard, language innovations that appear in the era of infodemia should be carefully selected for media texts, so as not to provoke recipients to further information noise around COVID-19;

(b) economic phenomena as illustrations of business and economic shifts in the country (bitcoin $=$ біткоїн, cryptocurrency $=$ криптовалюта, griponomics (flu + economy) $=$ грипономіка, business shuttle $=$ бiзнес-шатл, offshore zone $=$ офиорна зона, soft $/$ soft version $=\operatorname{coфm~} /$ софт-версія, free economy = вільна економіка) and cultural shifts, which are very often verbal illustrations of new cultural trends, nominations of new social groups, their language (often such illustrations are international): art installation $=$ apm-iнсталяці is, cuming-out $=$ камінг-ауm, crazy $=\kappa$ кейзi, sale $=$ сейл, discount $=\partial и с к о н m$, etc.

(c) scientific and technological progress associated with the emergence of new technical inventions, breakthrough technical support. As a rule, such innovations arise in developed countries, where the level of the economy is high, and in national languages these units are adapted phonetically and grammatically (most of these words are anglicisms): unbundling 
$=$ анбілдинг, update $=$ andeйm, gadget $=$ гаджеm, smartphone $=$ смарт $\varnothing о н$, account = акаунт, wipe = вайn, vaping = вейпінг, hypercar = гуперкар, etc.

(d) the phenomenon of "linguistic fashion" for certain words that have recently emerged in connection with the European integration of Ukraine (most words are popular in the EU): baby box (children's box) = бебі-бокс, pizza maker (pizza maker) = піцемейкер (виробник піции), cleaning manager (cleaner) $=\kappa \wedge і н і н г-$ менеджер (прибиральник), bullying = булінг (знущзання), travel = тревел (тревелінг), etc. Often such categories have absolute analogues in the language, but because of their popularity among speakers they actively function as a fashion tribute. Note that in the new Ukrainian spelling (2019), the overlap of the extralingual factor (distinguishing professions by gender) also manifested itself in language forms: laboratory assistant $=$ лаборант, лаборантеса, dean = дека, де$\kappa a н \kappa a$, graduate student $=$ аспірант, асnірантиа, diplomat $=$ дипломат, дипломатиа, professor $=$ професор, професорша / професорка, military = військовий, військовиц, кетологиня, etc. which stylistically have different modalities - ironic-evaluative as for modern professions that are not correlated with the social hierarchy (baroness $=$ баронеса, cossack $=$ козачка, barber = барберша, цุирюльничка еtс.), attribution to family and family ties (wife of an academic $=$ aкадеми, wife of an cosmonaut $=$ космонавтиа , etc.), or marked only by the conversational sphere, not developed in the literary tradition (rector $=$ ректор, ректорка, physicist $=$ фiзик, фізичка, chemist $=$ хімік, хімічка, analyst = аналітик, аналітичка, etc.). It should be noted that in modern media communication such units are increasingly emerging and actively functioning, which is a consequence of the mentioned "linguistic fashion". Obviously, this should be a part of the professional work of a media ecologist, and it should be marked accordingly in our e-file;

(e) information evolution associated with globalized processes. We are talking about new categories that have appeared as a result of the expansion of mass information processes - the emergence of social networks, new radio and TV genres / formats, language innovations of internet communicants: internet post $=$ інтернет-пост, Telegram channel $=$ телеграм-канал, Instagram stories = сторіз в інстаграм, like $/$ dislike $=$ лайкнути / дизлайкнути, fake news = фейк-ньюз, etc. for more such categories, see the dictionary "New words and phraseologisms / idioms in the Ukrainian mass media: dictionary" (Shevchenko, Syzonov 2017-2021).

It should be noted that the latter is extremely important not only for language changes, but also for changes in the media space: information delivery formats are changing, recipients' requirements for media flow are growing and media competition is emerging. All this invariably leads to the renewal of the language in media communication, which researchers in the field of media linguistics and media ecology pay close attention to.

It is extralingual factors in combination with (a) the sphere from which innovation entered the mass consciousness; (b) the genre in which media innovation functioned for the first time; (c) the psycholin- 
guistic marker by which innovation is identified by the speaker; (d) the time of the appearance of a new unit and their (e) transformation, etc. that are taken into account when creating an e-file. We will take these factors into account in future as this will help track the dynamics of the Ukrainian language at a specific time and with attention to the background knowledge of recipients.

\section{CONCLUSIONS}

Speaking about the purity of the media language (media ecological aspect), we tried to outline the e-file of language innovations of the Ukrainian language for further lexicographic representation. Knowledge of media ecology, therefore, allows us to make the most complete screening of modern Ukrainian media communication and provide a comprehensive picture of the eco-portrait of a modern Ukrainian in the context of dynamic processes in the language.

Information awareness and media literacy are key components of modern information hygiene and media ecology: "media literacy education is the key to understanding the modern information society: today, a person is simply obliged to be media-competent, otherwise he or she will not only become an easy victim

\section{References}

Corpus of Ukrainian language texts. 2003 - Kopnyc текстів украӥнської мови. <www.mova.info> [accessed on 202104 05]

Deslandes G., Painter-Morland M. 2012. Rethinking accountability in contemporary media organizations, Studies in Communication Sciences. № 12(1): 12-16. https://doi.org/10.1016/j.scoms.2012.06.004 [accessed on 202104 05]

Flayhan D. 2001. Cultural studies and media ecology: Meyrowitz's medium theory and Carey's cultural studies. Atlantic Journal of Communication. № 9(1): 21-44. https://doi.org/10.1080/154 56870109367396 [accessed on 202104 05] of numerous media manipulations, but will not be able to fully enter the differentiated world of media culture" (Tselykh 2020: 104). Considering language innovations in a media ecological context, it is necessary to be attentive to their implementation and functioning, take into account the cultural-historical, socio-political, etymological and grammatical features of each language in order to remain correct in the spread of new language phenomena as a reflection of modern language changes.

The proposed concept of an e-filing system can become the basis for further comprehensive studies of language evolution under the influence of extralingual factors, which are presented in the article as verbal markers of changes in the society.

Karpilovs'ka Je.A., Kysljuk L.P., Klymenko N.F., Kryts'ka V.I., Puzdyrjeva T.K., Romanjuk Ju.V. 2013 - Карпідовська Є.А., Кислюк А.П., Клименко Н.Ф., Критська В.І., Пуздирєва Т.К., Романюк Ю.В. 2013. Активні ресурси сучасної української номінаціӥ: Ідеографічний словник нової лексики [Active resources of modern Ukrainian nomination: Ideographic dictionary of new vocabulary]. Київ: КММ.

Karpilovska Je. 2017 - Карпіловська Є. 2017. Роль картотеки «портретів слів» в укладанні словників нового покоління [The role of «portraits of words» card index in the compiling of new 
generation dictionaries]. Studia z Filologii Polskiej i Stowiańskiej, № 52: 93-109. https://doi.org/ 10.11649/sfps.2017.005 [accessed on 202104 05]

Korolyov Igor. 2021. Ecolinguistic Modes: Natural and Social Dominants. Logos. № 106: 100-108. https://doi.org/10.24101/logos.2021.11 [accessed on 202104 05]

Lum Casey 2006. Perspectives on Culture, Technology and Communication: The Media Ecology Tradition. Hampton Press.

Meyrowitz J. 1985. No sense of place. The impact of electronic media on social behavior. Oxford University Press.

Momaya K. 2019. The Past and the Future of Competitiveness Research: A Review in an Emerging Context of Innovation and EMNEs. International Journal of Global Business and Competitiveness volume. № 14: 1-10. https://doi.org/10.1007/ s42943-019-00002-3 [accessed on 202104 05]

Perrin D. 2006. Medienlinguistik. Konstanz: Utb.

Quasthoff U., Liebold S., Taubert N., Wolf T. 2007. Deutsches Neologismenwörterbuch: Neue Wörter und Wortbedeutungen in der Gegenwartssprache. Berlin: «Walter de Gruyter». https://doi.org/10. 1515/9783110911138 [accessed on 202104 05]

Ruotsalainen J., Heinonen S. 2015. Media ecology and the future ecosystemic society. European Journal of Futures Research. 3(1). https://doi. org/10. 1007/s40309-015-0068-7 [accessed on 202104 05]

Shevchenko L., Syzonov D. 2019. Electronic Filing System of Language Innovations in Media: Psycholinguistic Metric. Psycholinguistics. № 26(2): 358-367. https://doi.org/10.31470/2309-1797-201926-2-358-376 [accessed on 20210405$]$

\section{Endnotes}

1 The article has been prepared within the scope of the scientific project "Ecolinguistic Modes of Discursive Space of Ukraine in the European Mul-
Shevchenko L., Syzonov D. 2017-2021 - Шевченко П., Сизонов Д. 2017-2021. Нові слова та фразеологізми в українських мас-медіа: словник [Novi slova ta frazeologizmy $\mathrm{v}$ ukrainskyh masmedia [New words and phraseologisms / idioms in the Ukrainian mass media: dictionary]. Київ: «Київський університет».

Shevchenko L., Syzonov D., Dergach D. 2014 Шевченко А., Дергач Д., Сизонов Д. 2014. Медіалінгвістика: словник термінів і понять [Medialinguistics: glossary of terms and concepts]. Київ: «Київський університет».

Solganik G. 2002. - Солганик Г. 2002. Толковый словарь: Язык газеты, радио, телевидения [Ехplanatory dictionary: The language of newspapers, radio, television]. Москва: Изд-во АСТ.

Zhabotinskaya S.A. 2015 - Жаботинская С.А. 2015. Язык как оружие в войне мировоззрений. Майдан Антимайдан: словарь-тезаурус лексических инноваций [Language as a Weapon in the War of Ideologies. Maidan - Anti-Maidan: A DictionaryThesaurus of Lexical Innovation]. Киев: UACLaP. Cifuentes-Faura J. 2020. COVID-19 and Infodemics: How to Solve this Problem. International Journal of Media and Information Literacy. № 5(2), 145-152. https://doi.org/10.13187/ijmil.2020.2.145 [accessed on 202104 05]

Tselykh M. 2020. Media Education is the Key to Understanding the Modern Information Society. International Journal of Media and Information Literacy. № 5(1): 103-107. https://10.13187/ijmil. 2020.1.103 [accessed on 202104 05]

Zarocostas J. 2020. How to fight an infodemic. The Lancet. № 395 (Feb. 29). https://doi.org/10.1016/ S0140-6736(20)30461-X [accessed on 202104 05]

ticultural Continuum" (registration number 2020.02/0241) with the support of the National Research Foundation of Ukraine. 